\title{
Food consumption of children enrolled in five municipal schools according to socio-demographics characteristics
}

\section{Consumo alimentar de crianças matriculadas \\ em cinco escolas municipais de educação \\ infantil por características sociodemográficas}

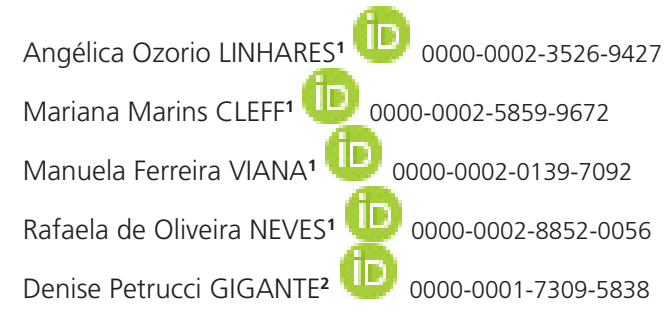

\section{A B S T R A C T}

\section{Objective}

To describe children food consumption in the five municipal schools in Pelotas, Rio Grande do Sul, and their main characteristics.

\section{Methods}

Cross-sectional study of children enrolled in five municipal schools. The mothers were interviewed at the school. The questionnaire about habitual food consumption was based on the guidelines of the Food and Nutrition Surveillance System. The data were entered in EpiData 3.1 and reviewed in Stata 14.0. The consumption frequency was reported according to each exposure category. Statistical tests based on Chi-Square test with 5\% significance level and adjusted analyses through Poisson regression were used.

\section{Results}

A total of 548 children were included. Females represented $51.1 \%$ of the total sample; the average age was 48.3 months. Children up to two years of age were those who consumed the most fruits and vegetables

1 Universidade Federal de Pelotas, Faculdade de Nutrição, Curso de Nutrição. R. Gomes Carneiro, n. 1, Porto, 96010-610, Pelotas, RS, Brasil. Correspondence to: A.O. LINHARES. E-mail: <angelica.ozorio@gmail.com>.

2 Universidade Federal de Pelotas, Faculdade de Nutrição, Programa de Pós-Graduação em Nutrição e Alimentos. Pelotas, RS, Brasil.

\section{How to cite this article}

Linhares AO, Cleff MM, Viana MF, Neves RO, Gigante DP. Food consumption of children enrolled in five municipal schools according to socio-demographics characteristics. Rev Nutr. 2020;33:e200123. https://doi.org/10.1590/1678-9 $865202033 e 200123$ 
while sweets were mostly consumed by older children, aged between three and four years. Unhealthy foods had a high frequency of consumption, with sweet being the most consumed (58.8\%), followed by packet snacks (53.3\%). In the adjusted analysis, eating meals in front of the screens remained associated with lower consumption of vegetables.

\section{Conclusion}

Eating meals in front of the screens reduces children's vegetables consumption. At the same time, the child's age and maternal education seem to have some influence on the consumption of unhealthy foods, indicating the need for nutritional education interventions.

Keywords: Food consumption. Child. Infant nutrition.

\section{RE S U M O}

\section{Objetivo}

Descrever o consumo alimentar de crianças de cinco escolas municipais de Pelotas, Rio Grande do Sul, e suas principais características.

\section{Métodos}

Estudo transversal, incluindo crianças de cinco escolas da rede municipal de educação infantil de Pelotas, Rio Grande do Sul. As mães foram entrevistadas na escola, sendo que as perguntas sobre consumo alimentar habitual foram elaboradas a partir das orientações do Sistema de Vigilância Alimentar e Nutricional. Os dados foram digitados no EpiData 3.1 e analisados no Stata 14.0. A frequência de consumo foi apresentada de acordo com cada categoria de exposição, e foram elaborados testes estatísticos baseados no qui-quadrado, sendo 5\% o nível de significância e análise ajustada por meio de regressão de Poisson.

\section{Resultados}

Foram incluídas 548 crianças, dentre as quais o sexo feminino representou 51,1\% e a média de idade foi de 48,3 meses. Crianças com até dois anos de idade são as que mais consomem frutas e legumes, e as com três e quatro anos são as que mais consomem doces. Os alimentos não saudáveis apresentaram elevada frequência de consumo, sendo o doce o mais consumido (58,8\%), seguido do salgadinho de pacote (53,3\%). Na análise ajustada, fazer refeições em frente às telas se manteve associado ao menor consumo de legumes.

\section{Conclusão}

Fazer as refeições em frente às telas diminui o consumo de legumes pelas crianças. Ao mesmo tempo, a idade da criança e a escolaridade materna parecem ter alguma influência no consumo de alimentos não saudáveis, indicando a necessidade de intervenções de educação nutricional.

Palavras-chave: Consumo de alimentos. Criança. Nutrição infantil.

\section{INTRODUCTION}

Several studies have pointed out that the consumption of unhealthy foods is ever more frequent among children under the age of five [1-6]. Studies that assessed some factors associated with children's food consumption show that the higher the family income and mothers' education, the greater the consumption of vegetables and fruits and that sweets and sausages are mostly consumed by children belonging to families earning less than one monthly minimum wage $[3,7]$.

Eating habits get established in the early years of life and are directly linked to the way food is introduced in the child's life, and further the behavior of infants food consumption is influenced by their parents' behavior [8]. The eating patterns established in this period appear to remain stable in the age group of two to six years of age and can be changed or discontinued in adolescence [9]. Inadequate eating habits cause immediate and long-term health problems, contributing to the early development of overweight and obesity in children and adults and, they can also be the cause of 
chronic diseases [10-12]. A cohort study conducted with children between three and four years and seven and eight years of age showed that the consumption of ultra-processed products at pre-school age was a predictor of greater increase in total cholesterol and Low Desinty Lipoprotein (LDL) cholesterol from preschool to school age [13].

The choice of foods to be consumed is also influenced by other factors, including sedentary lifestyle. Day screen time (TV, tablet, smartphone, video game or computer) has been used to determine sedentary behavior in children and adolescents and, consequently, the influence of this behavior on food intake [14-17]. According to the World Health Organization (WHO), zero screen time is recommended for children up to two years of age and for those children between two and five years old, this sedentary time should be a maximum of one hour a day [18]. Studies show a direct association between the habit of eating meals watching television as well as longer screen time with the lower consumption of fruits and vegetables and the higher intake of unhealthy foods $[17,19,20]$.

This study aims to describe the habitual consumption of healthy and unhealthy food by children enrolled in five municipal schools in the city of Pelotas, Rio Grande do Sul, and to evaluate the main characteristics related to diet consumption.

\section{METHODS}

This is a cross-sectional epidemiological study, carried out in five Escolas Municipais de Educação Infantil (EMEls, Municipal Early Childhood Education) in the city of Pelotas, RS, from August to November 2018. In 2018, the year in which those data were collected, the city of Pelotas had a total of 29 EMEls. The five schools included in this study are located in different neighborhoods in the city and were chosen at random. Children up to seven years of age attend two school shifts and, during this period, they eat five meals a day. All diets are planned by a nutritionist from the school food sector of the Municipal Department of Education and prepared by properly trained school cooks.

All children, aged up to 72 months, enrolled in the nursery, kindergarten and pre-primary school were eligible for the study. A child who could not be contacted at school after at least three visits was considered a loss. The mothers or guardians were interviewed at the school by trained college students, from the School of Nutrition of the Universidade Federal de Pelotas (UFPel, Federal University of Pelotas). The interviews were conducted at the beginning or at the end of the school shift in the five schools.

Information was collected on the characteristics of the children (gender and age), socioeconomic status of the family (family income, mothers' education) and behavior (time and meals in front of the screens). Age was calculated using the difference between the data collection date and the date of birth of each child, categorized into the following age groups: 0 to 24 months; 24.1 to 36 months; 36.1 to 48 months, 48.1 to 60 months and $\geq 60$ months. To assess the mothers' education, it was determined those who attended elementary school 1 (from one to five years of complete study), elementary school 2 (from six to nine years of complete study), who attended one or two years of high school and who completed high school and entered college (from nine to twelve years of study). Those who had completed their freshman year in college or continued their studies were included in the last category of mothers' education (13 years or more of study). Family income was calculated using the individual income of each person who had worked in the month prior to the interview plus some other source income reported, such as retirement and/or pension and also income from 
government welfare programs, such as the Bolsa Familia. Thus, the total family income in reais was presented in tertile, and in the first tertile, families that received no salary in the month prior to the interview were included up to those that received 1,322 reais, adding salaries and other income. In the second tertile were included those families that earned between 1,337 and 2,500 reais in the previous month and in the third tertile the group with the highest family income $(\geq 2,506$ reais). Screen time was assessed using the mother or guardian's self-report on the total number of minutes (when the answer was given in hours, the time was broken down in minutes) in which the child sat in front of TV, computer, tablet, smartphone or video game per day. Eating meals in front of the screen was investigated by a direct question to the mother or guardian whether the child used to have meals, eat or drink while watching TV, using the computer, tablet or cell phone.

To investigate habitual food consumption, a questionnaire was applied with 25 questions about the consumption of different foods. The questions intended to investigate food consumption were prepared based on the form of food consumption markers for children under five years of age issued by the Ministry of Health, Sistema de Vigilância Alimentar e Nutricional (SISVAN, Food and Nutrition Surveillance System) with yes and no answer options [21]. For the answer to be considered as yes, the mother or guardian should report the child's food consumption, taking into account the period in which the child was in the presence of his/her parents or guardians, that is, after school and at least four times on different days in the last week to be considered as an eating habit. Foods considered healthy were divided into three groups: fruits, vegetables and beans and unhealthy foods were divided into five groups: nuggets, hamburgers/sausages, packaged snacks (chips type), instant noodles, filled cookies/cakes, ready mix cakes and sweets/treats that are considered as ultra-processed products.

The data collected were entered twice in the EpiData 3.1 software [22]. The inconsistencies were corrected after verifying the correct answer in the questionnaire itself. All analyses were performed using the Stata version 15.0 statistical package [23]. Categorical variables were described by absolute and relative frequencies. The prevalences and relevant confidence intervals of the consumption of each food were calculated according to the categories of exposure. The statistical tests were based on the chi-square test. The level of significance adopted was $5 \%(p<0.05)$. The adjusted analysis was conducted using Poisson Regression, which considered sociodemographic variables in the first adjustment, and time and meals in front of the screens were later included in the analysis and were controlled for those who remained with $p<0.20$ in the first level.

Written consent from the mother or guardian was obtained before the information was collected by signing the Free and Informed Consent Form (FICF) in two copies. Parents and teachers were assured of the confidentiality of the information obtained during the study; it was emphasized that the child's identification would not be disclosed. The research project was authorized by the Secretária Municipal de Educação and approved by the Research Ethics Committee of the UFPel Nursing and Obstetrics School with the opinion n. 2,781,251.

\section{R E S U L T S}

The main characteristics of the children are shown in Table 1. 548 children were studied, $90.0 \%$ of the total students enrolled in five municipal pre-schools in Pelotas, RS. There was a slight predominance of females (51.3\%); most children were aged between three and six years (74.6\%) and slightly more than half $(51.1 \%)$ of the mothers had received thirteen or more years of school education. Regarding the sedentary screen time, $37.4 \%$ of the children stayed one hour a day, $40.5 \%$ more than two hours and half $(49.8 \%)$ of the children usually ate meals in front of the screens. 
Table 2 shows the frequency of healthy and unhealthy food consumption. Among healthy foods, beans were the most consumed (93.3\%) and among unhealthy foods, sweets and treats $(58.8 \%)$ were the most consumed.

Table 1. Demographic, socioeconomic and behavioral characteristics of children enrolled in five municipal pre-schools. Pelotas (RS), Brazil, 2019.

\begin{tabular}{|c|c|c|}
\hline \multirow{2}{*}{ Characteristics } & \multicolumn{2}{|c|}{ Children from $1-6$ years $(n=548)$} \\
\hline & $\mathrm{n}$ & $\%$ \\
\hline \multicolumn{3}{|l|}{ Gender } \\
\hline Male & 267 & 48.7 \\
\hline Female & 281 & 51.3 \\
\hline \multicolumn{3}{|l|}{ Age (months) ${ }^{*}$} \\
\hline $0-24.0$ & 59 & 10.6 \\
\hline $24.1-36.0$ & 83 & 14.9 \\
\hline $36.1-48.0$ & 110 & 19.7 \\
\hline $48.1-60.0$ & 146 & 26.1 \\
\hline$\geq 60.1$ & 161 & 28.8 \\
\hline \multicolumn{3}{|l|}{ Mother's education** } \\
\hline $1-5$ years & 59 & 10.9 \\
\hline $6-9$ years & 150 & 27.6 \\
\hline $10-12$ years & 251 & 46.1 \\
\hline$\geq 13$ years & 84 & 15.4 \\
\hline \multicolumn{3}{|l|}{ Family income } \\
\hline $1^{\text {st }}$ tertile $(+$ poor $)$ & 183 & 33.4 \\
\hline $2^{\text {nd }}$ tertile & 188 & 34.3 \\
\hline $3^{\text {rd }}$ tertile (+wealthy) & 177 & 32.3 \\
\hline \multicolumn{3}{|l|}{ Screen time } \\
\hline $0-60 \mathrm{~min}$ & 205 & 37.4 \\
\hline $61-120 \mathrm{~min}$ & 121 & 22.1 \\
\hline$\geq 121 \mathrm{~min}$ & 222 & 40.5 \\
\hline \multicolumn{3}{|l|}{ Meals in front of the screen } \\
\hline No & 275 & 50.2 \\
\hline Yes & 273 & 49.8 \\
\hline
\end{tabular}

Note: ${ }^{*}$ For eleven children, there was information on age, but there was no information on consumption; ${ }^{* *}$ For four children there was no information on mother's education ( $n=544)$; MW: Minimum Wage.

Table 2. Frequency distribution of healthy and unhealthy foods by preschoolers in five municipal schools of early childhood education. Pelotas (RS), Brazil, 2019.

\begin{tabular}{llll}
\hline \multirow{2}{*}{ Food } & \multicolumn{2}{c}{ Total } \\
\cline { 2 - 3 } & $\mathrm{n}$ & $\%$ & $\mathrm{Cl95 \%}$ \\
\hline Healthy food consumption & 503 & 91.8 & $89.5-94.1$ \\
$\quad$ Fruits & 455 & 83.0 & $79.9-86.2$ \\
$\quad$ Vegetables & 511 & 93.3 & $91.1-95.4$ \\
$\quad$ Beans & & & $40.5-48.9$ \\
Unhealthy food consumption & 245 & 44.7 & $49.1-57.5$ \\
$\quad$ Nuggets/hamburger/sausages & 292 & 53.3 & $33.2-41.3$ \\
$\quad$ Packet snacks & 204 & 37.2 & $49.4-57.8$ \\
$\quad$ Instant noodles & 293 & 53.5 & $54.6-62.9$ \\
$\quad$ Stuffed biscuit/ready-mix cake* & 322 & 58.8 & \\
$\quad$ Sweets or treats & & & \\
\hline
\end{tabular}

Note: *For a child there was no information about cake consumption; Cl: Confidence Interval. 
Table 3 shows the consumption frequency of foods considered healthy according to the children's characteristics. It can be observed that the children who consume fruits and vegetables more frequently are female, up to two years of age, have mothers with higher education and belong to families with higher family income, but the data are without statistical significance. Regarding the consumption of these foods considering time and meals in front of screens, it is observed that fruits are more consumed among children with less screen time $(p=0.189)$ but without statistical significance, whereas vegetables are more consumed by children who do not eat meals in front of screens and these data are statistically significant $(p=0.02)$. Beans are the healthy food most consumed by children in general; however it is noted that beans are more consumed by children whose mothers have less education and family income, with no statistically significant difference.

Table 4 shows the frequency of consumption of foods considered unhealthy, according to the characteristics of the children. Sweet is the food most consumed by girls as compared to boys ( $p=0.09)$ and significant differences are observed in relation to children's age and mothers' education. Thus, the frequency of consumption was higher in children between three and four years of age and whose mothers have less education. The higher consumption of sweets by children belonging to the families of the lowest income tertiles was not statistically significant. Children with more than 2 hours screen time are those who consume sweets more frequently

Table 3. Habitual consumption of healthy food among children enrolled in five municipal pre-schools according to demographic, socioeconomic and behavioral characteristics. Pelotas (RS), Brazil, 2019

\begin{tabular}{|c|c|c|c|c|c|c|c|c|c|}
\hline \multirow{2}{*}{ Variables } & \multicolumn{2}{|c|}{ Fruits } & \multirow{2}{*}{$p$ of trend } & \multicolumn{2}{|c|}{ Vegetables } & \multirow{2}{*}{$p$ of trend } & \multicolumn{2}{|c|}{ Beans } & \multirow{2}{*}{$p$ of trend } \\
\hline & $\mathrm{n}$ & $\%$ & & $n$ & $\%$ & & $n$ & $\%$ & \\
\hline Gender & & & 0.518 & & & 0.401 & & & 0.993 \\
\hline Male & 243 & 91.0 & & 218 & 81.7 & & 249 & 93.3 & \\
\hline Female & 260 & 92.5 & & 237 & 84.3 & & 262 & 93.2 & \\
\hline Age (months) & & & 0.933 & & & 0.059 & & & 0.475 \\
\hline $0-24$ & 56 & 94.9 & & 54 & 91.5 & & 55 & 93.2 & \\
\hline $24.1-36$ & 76 & 92.7 & & 73 & 89.0 & & 77 & 93.9 & \\
\hline $36.1-48$ & 93 & 90.3 & & 83 & 80.6 & & 97 & 94.2 & \\
\hline $48.1-60$ & 127 & 92.7 & & 110 & 80.3 & & 128 & 93.4 & \\
\hline$\geq 60.1$ & 131 & 92.9 & & 115 & 81.6 & & 129 & 91.5 & \\
\hline Mother's education & & & 0.535 & & & 0.816 & & & 0.313 \\
\hline $1-5$ years & 53 & 89.8 & & 50 & 84.8 & & 58 & 98.3 & \\
\hline $6-9$ years & 138 & 92.0 & & 126 & 84.0 & & 139 & 92.7 & \\
\hline $10-12$ years & 229 & 91.2 & & 201 & 80.1 & & 235 & 93.6 & \\
\hline$\geq 13$ years & 79 & 94.0 & & 75 & 89.3 & & 77 & 91.7 & \\
\hline Family income & & & 0.633 & & & 0.788 & & & 0.178 \\
\hline $1^{\text {st }}$ tertile & 168 & 91.8 & & 155 & 84.7 & & 175 & 95.6 & \\
\hline $2^{\text {nd }}$ tertile & 170 & 90.4 & & 148 & 78.7 & & 173 & 92.0 & \\
\hline $3^{\text {rd }}$ tertile & 165 & 93.2 & & 152 & 85.9 & & 163 & 92.1 & \\
\hline Screen time & & & 0.189 & & & 0.020 & & & 0.130 \\
\hline $0-60 \mathrm{~min}$ & 195 & 95.1 & & 179 & 87.3 & & 195 & 95.1 & \\
\hline $61-120 \mathrm{~min}$ & 105 & 86.8 & & 101 & 83.5 & & 113 & 93.4 & \\
\hline$\geq 121 \mathrm{~min}$ & 203 & 91.4 & & 175 & 78.8 & & 203 & 91.4 & \\
\hline Meals in front of the screen & & & 0.154 & & & 0.008 & & & 0.120 \\
\hline Yes & 246 & 90.1 & & 215 & 78.8 & & 250 & 91.6 & \\
\hline No & 257 & 93.5 & & 240 & 87.3 & & 261 & 94.9 & \\
\hline
\end{tabular}


$(p=0.05)$; the same occurs with children eating meals in front of screens, but in this case without significant difference. One can verify that the lower the mother's level of education, the greater the consumption of sausages $(p<0.01)$, snacks $(p<0.01)$, instant noodles $(p<0.01)$ and sweets $(p=0.05)$. The consumption of snacks is higher as screen time increases $(p=0.01)$ and among children who eat in front of screens $(p=0.01)$.

The adjusted analysis (Table 5) confirms that eating meals in front of screens remains associated with less consumption of vegetables, regardless of mothers' education and screen time. In addition, greater mothers' education protects the child from the consumption of unhealthy foods, with the exception of sweets. The effects of screen time and eating in front of screens associated with a higher consumption of snacks observed in the crude rates analysis disappeared when adjusting for mothers' age and education, suggesting that older children and whose mothers have less education would have a stronger influence on consumption of snacks. In summary, the adjusted analysis shows that the child's age and mothers' education were the variables that were most tightly associated with the consumption of unhealthy foods.

Table 4. Habitual consumption of unhealthy foods by children enrolled in five municipal pre-schools according to demographic, socioeconomic and behavioral characteristics. Pelotas (RS), Brazil, 2019.

\begin{tabular}{|c|c|c|c|c|c|c|c|c|c|c|c|c|c|c|c|}
\hline \multirow{2}{*}{ Variables } & \multicolumn{2}{|c|}{ Stuffed meat } & \multirow{2}{*}{$\begin{array}{l}p \text { of } \\
\text { trend }\end{array}$} & \multicolumn{2}{|c|}{ Snacks } & \multirow{2}{*}{$\begin{array}{l}p \text { of } \\
\text { trend }\end{array}$} & \multicolumn{2}{|c|}{ Noodles } & \multirow{2}{*}{$\begin{array}{l}p \text { of } \\
\text { trend }\end{array}$} & \multicolumn{2}{|c|}{ Cookies } & \multirow{2}{*}{$\begin{array}{l}p \text { of } \\
\text { trend }\end{array}$} & \multicolumn{2}{|c|}{ Sweets } & \multirow{2}{*}{$\begin{array}{l}p \text { of } \\
\text { trend }\end{array}$} \\
\hline & $n$ & $\%$ & & $n$ & $\%$ & & $n$ & $\%$ & & $n$ & $\%$ & & $n$ & $\%$ & \\
\hline Gender & & & 0.453 & & & 0.575 & & & 0.437 & & & 0.392 & & & 0.086 \\
\hline Male & 115 & 43.1 & & 139 & 52.1 & & 95 & 35.6 & & 223 & 83.5 & & 147 & 55.1 & \\
\hline Female & 130 & 46.3 & & 153 & 54.5 & & 109 & 38.8 & & 226 & 80.7 & & 175 & 62.3 & \\
\hline Age (months) & & & 0.001 & & & 0.003 & & & 0.019 & & & 0.646 & & & 0.040 \\
\hline $0-24$ & 14 & 23.7 & & 19 & 32.2 & & 13 & 22.0 & & 48 & 81.4 & & 21 & 35.6 & \\
\hline $24.1-36$ & 35 & 42.7 & & 40 & 48.8 & & 29 & 35.4 & & 70 & 85.4 & & 44 & 53.7 & \\
\hline $36.1-48$ & 40 & 38.8 & & 56 & 54.4 & & 41 & 39.8 & & 85 & 85.5 & & 70 & 68.0 & \\
\hline $48.1-60$ & 75 & 54.7 & & 83 & 60.6 & & 52 & 38.0 & & 110 & 80.9 & & 84 & 61.3 & \\
\hline$\geq 60.1$ & 71 & 50.4 & & 81 & 57.5 & & 61 & 43.3 & & 115 & 81.6 & & 83 & 58.9 & \\
\hline $\begin{array}{l}\text { Mother's } \\
\text { education }\end{array}$ & & & 0.000 & & & 0.000 & & & 0.000 & & & 0.203 & & & 0.046 \\
\hline $1-5$ years & 36 & 61.0 & & 38 & 64.4 & & 32 & 54.2 & & 53 & 89.8 & & 43 & 72.8 & \\
\hline 6-9 years & 73 & 48.0 & & 93 & 61.2 & & 66 & 43.4 & & 124 & 82.1 & & 89 & 58.6 & \\
\hline $10-12$ years & 29 & 52.7 & & 34 & 61.8 & & 25 & 45.5 & & 46 & 83.6 & & 40 & 72.7 & \\
\hline$\geq 13$ years & 105 & 37.8 & & 123 & 44.2 & & 79 & 28.4 & & 223 & 80.2 & & 146 & 52.5 & \\
\hline Family income & & & 0.940 & & & 0.612 & & & 0.200 & & & 0.652 & & & 0.425 \\
\hline $1^{\text {st }}$ tertile & 80 & 43.7 & & 100 & 54.6 & & 74 & 40.4 & & 153 & 83.6 & & 110 & 60.1 & \\
\hline $2^{\text {nd }}$ tertile & 87 & 46.3 & & 100 & 53.2 & & 70 & 37.2 & & 152 & 80.9 & & 113 & 60.1 & \\
\hline $3^{\text {rd }}$ tertile & 78 & 44.1 & & 92 & 52.0 & & 60 & 33.9 & & 144 & 81.8 & & 99 & 55.9 & \\
\hline Screen time & & & 0.231 & & & 0.009 & & & 0.201 & & & 0.798 & & & 0.050 \\
\hline $0-60 \mathrm{~min}$ & 84 & 41.0 & & 98 & 47.8 & & 72 & 35.1 & & 167 & 81.5 & & 109 & 53.2 & \\
\hline $61-120 \mathrm{~min}$ & 57 & 47.1 & & 60 & 49.6 & & 41 & 33.9 & & 99 & 82.5 & & 74 & 61.2 & \\
\hline$\geq 121 \mathrm{~min}$ & 104 & 46.9 & & 134 & 60.4 & & 91 & 41.0 & & 183 & 82.4 & & 139 & 62.6 & \\
\hline $\begin{array}{l}\text { Meals in front } \\
\text { of the screen }\end{array}$ & & & 0.738 & & & 0.013 & & & 0.067 & & & 0.808 & & & 0.426 \\
\hline Yes & 124 & 45.4 & & 160 & 58.6 & & 112 & 41.0 & & 223 & 81.7 & & 165 & 60.4 & \\
\hline No & 121 & 44.0 & & 132 & 48.0 & & 92 & 33.5 & & 226 & 82.5 & & 157 & 57.1 & \\
\hline
\end{tabular}


Table 5. Adjusted analysis for healthy and unhealthy food consumption among children enrolled in five municipal pre-schools according to sociodemographic and behavioral characteristics. Pelotas (RS), Brazil, 2019.

\begin{tabular}{|c|c|c|c|c|c|c|c|c|}
\hline \multirow{3}{*}{ Variables } & \multicolumn{8}{|c|}{ Adjusted analysis } \\
\hline & \multicolumn{2}{|c|}{ Fruits } & \multicolumn{2}{|c|}{ Vegetables } & \multicolumn{2}{|c|}{ Beans } & \multicolumn{2}{|c|}{ Embedded } \\
\hline & $\begin{array}{c}\text { Prevalence } \\
\text { ratio }\end{array}$ & $\mathrm{C} 195 \%$ & $\begin{array}{c}\text { Prevalence } \\
\text { ratio }\end{array}$ & $\mathrm{C} 195 \%$ & $\begin{array}{c}\text { Prevalence } \\
\text { ratio }\end{array}$ & $\mathrm{C} 195 \%$ & $\begin{array}{c}\text { Prevalence } \\
\text { ratio }\end{array}$ & $\mathrm{C} 195 \%$ \\
\hline Gender & \multicolumn{2}{|c|}{$p=0.39$} & \multicolumn{2}{|c|}{$p=0.34$} & \multicolumn{2}{|c|}{$p=0.86$} & \multicolumn{2}{|c|}{$p=0.59$} \\
\hline Male & \multicolumn{2}{|c|}{1.00} & \multicolumn{2}{|c|}{1.00} & \multicolumn{2}{|c|}{1.00} & \multicolumn{2}{|c|}{1.00} \\
\hline Female & 1.02 & $0.97-1.07$ & 1.03 & $0.96-1.12$ & 1.01 & $0.96-1.06$ & 1.05 & $0.87-1.26$ \\
\hline Age (months) & \multicolumn{2}{|c|}{$p=0.97$} & \multicolumn{2}{|c|}{$p=0.02$} & \multicolumn{2}{|l|}{$p=0.35$} & & \\
\hline $0-24$ & 1.01 & $0.94-1.10$ & 1.12 & $1.00-1.27$ & 1.03 & $0.94-1.14$ & 0.53 & $0.33-0.87$ \\
\hline $24.1-36$ & 0.99 & $0.92-1.07$ & 1.09 & $0.98-1.22$ & 1.04 & $0.96-1.11$ & 0.89 & $0.66-1.19$ \\
\hline $36.1-48$ & 0.97 & $0.90-1.05$ & 1.00 & $0.88-1.13$ & 1.04 & $0.98-1.12$ & 0.79 & $0.59-1.05$ \\
\hline $48.1-60$ & 1.00 & 0.93-1.07 & 0.99 & $0.89-1.11$ & 1.03 & $0.97-1.10$ & 1.10 & $0.88-1.38$ \\
\hline$\geq 60.1$ & & & & & & & & \\
\hline Mothers' education & & & & & $p=$ & & & \\
\hline $1-5$ years & 1.00 & - & 1.00 & & & & & \\
\hline $6-9$ years & 1.06 & $0.95-1.18$ & 0.96 & $0.84-1.08$ & 0.92 & $0.88-0.97$ & 0.76 & $0.59-0.97$ \\
\hline $10-12$ years & 1.03 & $0.93-1.15$ & 0.90 & $0.80-1.02$ & 0.94 & $0.91-0.97$ & 0.67 & $0.53-0.85$ \\
\hline$\geq 13$ years & 1.07 & $0.96-1.08$ & 0.99 & $0.85-1.14$ & 0.92 & $0.84-0.99$ & 0.41 & $0.27-0.62$ \\
\hline Family income & & & & & & & & \\
\hline $1^{\text {st }}$ tertile & & & & & & & & \\
\hline $2^{\text {nd }}$ tertile & 0.98 & $0.92-1.04$ & 0.92 & $0.83-1.01$ & 0.96 & $0.91-1.01$ & 1.06 & $0.85-1.34$ \\
\hline $3^{\text {rd }}$ tertile & 1.01 & $0.95-0.99$ & 0.97 & $0.88-1.08$ & 0.97 & $0.91-1.03$ & 1.23 & $0.98-1.55$ \\
\hline Screen time & & & & & & & & \\
\hline $0-60 \mathrm{~min}$ & 1.03 & $0.98-1.09$ & 1.06 & $0.96-1.16$ & 1.09 & $1.00-1.19$ & 0.92 & $0.73-1.15$ \\
\hline $61-120 \mathrm{~min}$ & 0.95 & $0.87-1.03$ & 1.04 & $0.96-1.15$ & 1.04 & $0.99-1.10$ & 0.97 & $0.77-1.23$ \\
\hline$\geq 121 \mathrm{~min}$ & & & & & & & & \\
\hline Meals in front of the screen & & & & & & & & \\
\hline Yes & & & & & & & & \\
\hline No & 1.03 & $0.98-1.08$ & 1.08 & $1.00-1.17$ & 1.02 & $0.88-1.01$ & 1.08 & $0.89-1.30$ \\
\hline & & & & & analysis & & & \\
\hline Variablec & & & & etti & $\mathrm{Coc}$ & & & \\
\hline & $\begin{array}{c}\text { Prevalence } \\
\text { ratio }\end{array}$ & $\mathrm{Cl} 195 \%$ & $\begin{array}{c}\text { Prevalence } \\
\text { ratio }\end{array}$ & $\mathrm{C} 195 \%$ & $\begin{array}{c}\text { Prevalence } \\
\text { ratio }\end{array}$ & $\mathrm{Cl} 95 \%$ & $\begin{array}{c}\text { Prevalence } \\
\text { ratio }\end{array}$ & $\mathrm{C} 195 \%$ \\
\hline Gender & & & & & $p=$ & & & \\
\hline Male & & & & & & & & \\
\hline Female & 1.05 & $0.89-1.23$ & 1.13 & $0.91-1.40$ & 1.03 & $0.88-1.20$ & 1.14 & $0.98-1.32$ \\
\hline Age (months) & & & & & & & & \\
\hline $0-24$ & 0.62 & $0.42-0.92$ & 0.62 & $0.37-1.04$ & 0.52 & $0.34-0.80$ & 0.63 & $0.43-0.92$ \\
\hline $24.1-36$ & 0.89 & $0.68-1.16$ & 0.89 & $0.63-1.25$ & 0.86 & $0.67-1.10$ & 0.92 & $0.72-1.17$ \\
\hline $36.1-48$ & 0.98 & $0.78-1.24$ & 0.97 & $0.71-1.31$ & 0.89 & $0.71-1.11$ & 1.18 & $0.97-1.43$ \\
\hline $48.1-60$ & 1.06 & $0.87-1.30$ & 0.90 & $0.67-1.19$ & 1.03 & $0.85-1.24$ & 1.04 & $0.86-1.26$ \\
\hline$\geq 60.1$ & & & & & & & & \\
\hline Mothers' education & & & & & $p<$ & & & \\
\hline $1-5$ years & & & & & & & & \\
\hline $6-9$ years & 0.96 & $0.76-1.21$ & 0.81 & $0.60-1.09$ & 1.04 & $0.81-1.34$ & 0.86 & $0.69-1.08$ \\
\hline $10-12$ years & 0.76 & $0.60-0.97$ & 0.64 & $0.48-0.86$ & 0.95 & $0.74-1.22$ & 0.82 & $0.67-1.01$ \\
\hline$\geq 13$ years & 0.59 & $0.41-0.83$ & 0.35 & $0.21-0.60$ & 0.60 & $0.40-0.89$ & 0.83 & $0.63-1.10$ \\
\hline Family income & & & & & $p=$ & & & \\
\hline $1^{\text {st }}$ tertile & & & & & & & & \\
\hline $2^{\text {nd }}$ tertile & 1.01 & $0.83-1.23$ & 0.91 & $0.70-1.19$ & 1.06 & $0.88-1.28$ & 0.99 & $0.83-1.18$ \\
\hline $3^{\text {rd }}$ tertile & 1.16 & $0.95-1.42$ & 1.05 & $0.80-1.38$ & 1.09 & $0.89-1.32$ & 0.99 & $0.82-1.20$ \\
\hline Screen time & & & & & & & & \\
\hline $0-60 \mathrm{~min}$ & 0.90 & $0.74-1.08$ & 0.93 & $0.73-1.20$ & 0.90 & $0.75-1.08$ & 0.89 & $0.75-1.07$ \\
\hline $61-120 \mathrm{~min}$ & 0.85 & $0.68-1.05$ & 0.82 & $0.61-1.11$ & 0.90 & $0.73-1.10$ & 1.01 & $0.84-1.22$ \\
\hline$\geq 121 \mathrm{~min}$ & & & & & & & & \\
\hline Meals in front of the screen & & & & & $p=$ & & & \\
\hline Yes & & & & & & & & \\
\hline No & 0.90 & $0.76-1.06$ & 0.90 & $0.72-1.13$ & 1.01 & $0.86-1.18$ & 1.02 & $0.88-1.20$ \\
\hline
\end{tabular}




\section{DISCUSSION}

The results presented reveal that most children habitually consume fruits, vegetables and beans. An expressive number of children consume sweets and treats, stuffed biscuits and packaged snacks, foods classified as ultra-processed because they contain excessive amounts of calories, salt, sugar, fats and additives, pointing to an unhealthy eating pattern [24].

Assessing the consumption of the three foods, considered in this study, to be markers of healthy eating, the result is satisfactory, since most of the foods consumed by children must be in the group of fresh or minimally processed foods, as in the case of fruits, vegetables and beans [24]. A study carried out with two-year-old children who attended municipal schools in Monte Carlos, MG, known as daycare centers, also found a high prevalence of fruit consumption (85.2\%), vegetables (76.3\%) and beans (90.8\%) [25]. Institutionalization seems to have a protective effect on children with regard to the consumption of healthy food, considering that children receive this type of food in municipal schools or daycare centers [4]. A study carried out with children from 15 daycare centers in Juiz de Fora, MG, investigated the previous day's food consumption of healthy and unhealthy markers and found a low consumption of vegetables and fruits after the time spent in the daycare center [26].

When evaluating the results of this study in relation to the consumption of healthy foods by sociodemographic characteristics, no statistically significant difference was found when determined by gender, age, mothers' education and family income. When the consumption of fruits, vegetables and beans was reviewed according to the behavioral variables, it was noted that vegetables are consumed more frequently by children who do not eat meals in front of the screens $(p=0.05)$.

The five foods considered markers of unhealthy eating had a high consumption frequency, despite the fact that the Ministry of Health, in the Food Guide for Brazilian Children Under two years of age, recommends that these types of ultra-processed foods be not offered to children [24]. This result was similar to that found in the study that assessed data regarding children, aged between two and four years, made available in SISVAN reports from all over Brazil [27]. When considering the child's age and mothers' education, statistically significant differences were found in the consumption of four of the five unhealthy foods. In general, the group of older children and those with mothers with less education are those who consume more unhealthy foods. In Porto Alegre, RS, investigation with children from a basic health unit showed that the contribution of ultra-processed foods is significant in infant feeding and as the child's age increases the consumption proportion of these foods also increases [28]. The study conducted in 15 municipal daycare centers in Juiz de Fora showed that children older than 12 months consumed a higher amount of unhealthy markers [26]. A study that included children from nurseries in eight public and philanthropic daycare centers in the city of São Paulo, SP showed that low mothers' education doubles the risk of early introduction of snacks and instant noodles [29].

Considering the screen exposure as an independent variable, the gross analysis shows a higher consumption of packet snacks among children with extensive screen time or who ate meals in front of the screens, although this association lost its effect after the adjusted analysis, showing that the children's age and mothers' education have a stronger effect on the consumption of snacks; screen time should be considered when studying children's eating behavior. A survey carried out in Lithuania with 847 children aged two to five years shows that more screen time was associated with a higher frequency of unhealthy foods consumption [30]. Few studies have so far addressed the prevalence 
of food consumption by children in the preschool age group and the relationship with screen time. A study of 126 UK children aged between five and six years showed that $25 \%$ of them had two or three health risk behaviors, including having meals in front of the TV [31]. A study that investigated the factors associated with the consumption of unhealthy dietary markers in schoolchildren with high vulnerability to health, attending public schools in a Brazilian capital, showed that the chance of excessive consumption of unhealthy foods was higher among children than usually eat in front of the screens [32]. A study from Spain, using data from the ALADINO survey, showed that longer screen time was associated with a higher consumption frequency of energy-rich, low-micronutrient products and a lower consumption frequency of fruits and vegetables [17]. Our study identified, in the adjusted analysis, that children eating meals in front of the screens consume less vegetables. Therefore, more investigations are needed in this age group; however, parents and caregivers who seek to encourage healthy eating should be warned about this behavior. Parents and caregivers should be encouraged to avoid excessive use of screens by their young children [18], as this behavior can be detrimental to the nutrition of children with repercussions in adolescence. A study with adolescents from 1,247 schools in 124 Brazilian municipalities showed high exposure to screens: more than half of adolescents had their meals almost always or always in front of the TV, and $39.6 \%$ ate snacks in front of the screens [19].

When reviewing this study's results, it is important to consider that all children included in this study attended municipal early childhood education schools from Monday to Friday in two shifts, morning and afternoon, and at school they had five meals during the day; those meals' menu is set by nutritionists and prepared at the school by qualified cooks. It is worth remembering that the aim of this study was to investigate the habitual consumption of healthy and unhealthy food in general, investigating the consumption of each of the selected foods, whether at school or at home, including the home of grandparents and relatives, in a frequency of at least four times a week.

In this framework, it is alarming to see the habitual consumption of unhealthy foods by children enrolled in municipal pre-schools, since more than half consume sweets or treats and stuffed cookies at least four times a week. Considering that children have lunch and dinner at school, it is of concern to find out the high frequency of habitual consumption of nuggets, hamburgers, sausages and instant noodles. The high consumption of ultraprocessed, unhealthy foods, by two-year-old children was also observed in a study conducted in Montes Claros, MG [25].

Considering that children are not allowed to take any type of food from home to school, these results reveal that unhealthy foods are consumed by children in a family environment, after school time. The family is primarily responsible for the development of children's eating habits, and may influence, in a positive or negative manner, their children's eating behavior; however, the family is not the only one responsible [33]. A review study found that the development of eating behavior depends on the interaction of factors related to the child and caregivers and is affected by several factors related to the individual's life, such as the physical, social, family, cultural and media environment [34].

In this connection, it is important to highlight the role of the state in protecting and promoting health through healthy eating. The Programa Nacional de Alimentação Escolar (PNAE, National School Feeding Program) offers food and food and nutrition education actions to students in all stages of public basic education. Recently, the Fundo Nacional de Desenvo/vimento da Educação (FNDE, National Education Development Fund) released Resolution 6/2020 which updates the rules for the execution of the PNAE; the norm ensures a healthy diet for students by increasing the supply of natural foods, such as fruits and vegetables, restricting processed products and 
banning ultra-processed foods, sugar, honey and sweeteners in culinary preparations and drinks for children up to three years of age [35]. It is important that these recommendations be regulated, since there is a study showing that the introduction of soda and industrialized juices occurred before the first year of life, in more than half of the infants enrolled in eight public daycare centers in Santo Amaro, SP [36]. Although these drinks were not assessed in this study, it is important to note that, according to the Food Guide for Brazilian Children Under 2 years of age, juices, in general, should not be offered to children under one year of age and sugar should not be offered before the age of two [24].

Furthermore, the results found in the Santo Amaro, SP study draws attention to the fact that children enrolled in municipal day care centers are receiving these sugary drinks at very early age, which makes us reflect that families are responsible for consuming this type of food. A study [37] with secondary data from the Pesquisa Nacional de Saúde (PNS, National Health Survey), in 2013, showed that family habits influence the higher consumption of sugary drinks in Brazilian children under two years of age. In this perspective, there is no doubt that the school and families need to be connected towards the same objective with regard to guidelines and practices in infant feeding in order to convey safety and consistency to the child who is developing his/her eating habits.

Another point that requires attention is the fact that children who eat sweets and snacks more often are those who reveal more screen time and those who consume more snacks are actually those who have their meals in front of screens. Even losing statistical significance after the adjusted analysis, these results enhance the WHO recommendations indicating that the screen time should not exceed one hour per day for children over two years of age [18]. A study with children assessed in the PNS found a positive association between higher consumption of sugary drinks and the habit of watching television for three hours or more [37].

The fact that the consumption of sweets and snacks is more prevalent among children who spend more time exposed to screens is of concern since sedentary leisure, time in front of the TV exceeding two hours a day, and at the same time the intake of unhealthy foods, with high energy density, cause children to acquire habits that are harmful to their health, such as sedentarism, and therefore they can become overweight children [14-16]. At the same time, research show that the media is a strong influencer of food choices [14,38].

It is important to highlight that our study's sample included only children enrolled in municipal early childhood education schools, which prevents the extrapolation of results to the whole children population of the preschool age group of Pelotas, RS. Children who were not attending or who were out of school on the days of the survey were excluded and may represent a different group, with worse behaviors related to eating habits. Still as a limitation, the investigation of food consumption was based only on the frequency of weekly consumption of certain types of food; however SISVAN recommends these markers considering the investigation of total weekly consumption allowing to identify the children's recent eating habits [21].

\section{CONCLUSION}

This study identified that a meal in front of screens causes children to eat less vegetables and that only children under two years of age were protected from the consumption of unhealthy foods such as sausages, snacks, cookies and sweets. In addition, mothers with a higher level of education would be more informed about infant feeding, offering less often foods considered unhealthy. 
Information about the types of food most consumed by children of the municipal schools surveyed and the factors associated with such consumption should be extended to all EMEls and inspire the development of food and nutrition education and health promotion regular actions aimed at children and mothers in the school environment leading to the family environment. Both settings are considered ideal for promoting health and influencing the development process of the child's eating habits.

Access to reliable information enhances the autonomy of families and caregivers to critically choose foods and propose changes regarding feeding practices [24]. It is recommended that periodic meetings with mothers and children's guardians be held at school to discuss issues related to health and, above all, to children's diet.

CONTRIBUTORS

AO LINHARES, and DP GIGANTE were responsible for the project, fieldwork, analysis, data interpretation and article writing. MM CLEFF, MF Viana, and RO Neves were responsible for collecting and interpreting the data. All authors reviewed and approved the final version of the article.

\section{REFERE N CES}

1. Bortolini GA, Gubert MB, Santos LMP. Consumo alimentar entre crianças brasileiras com idade de 6 a 59 meses. Cad Saúde Pública. 2012;28:1759-71.

2. Alves MN, Muniz LC, Vieira MFA. Consumo alimentar entre crianças brasileiras de dois a cinco anos de idade: Pesquisa Nacional de Demografia e Saúde (PNDS), 2006. Ciênc Saúde Coletiva. 2013;18:3369-77.

3. Souza RLV, Madruga SW, Gigante DP, Santos IS, Barros AJD, Assunção MCF. Padrões alimentares e fatores associados entre crianças de um a seis anos de um município do Sul do Brasil. Cad Saúde Pública. 2013;29:2416-26.

4. Carvalho CA, Almeida Fonseca PC, Priore SE, Franceschibi, SCC, Novaes JF. Food consumption and nutritional adequacy in Brazilian children: a systematic review. Rev Paul Pediatr. 2015;33(2):211-21.

5. Leal KK, Schneider BC, França GVA, Gigante DP, Santos I, Assunção MCF. Qualidade da dieta de pré-escolares de 2 a 5 anos residentes na área urbana da cidade de Pelotas, RS. Rev Paul Pediatr. 2015;33(3):310-7.

6. Relvas GRB, Santos Buccini G, Venancio SI. Ultra-processed food consumption among infants in primary health care in a city of the metropolitan region of Sao Paulo, Brazil. J Pediatr. 2018;(95):584-92.

7. Karnopp EVN, Vaz JS, Schafer AA, Muniz LC, Souza RLV, Santos I, et al. Food consumption of children younger than 6 years according to the degree of food processing. J Pediatr. 2017;93(1):70-8.

8. Yee $A Z$, Lwin MO, Ho SS. The influence of parental practices on child promotive and preventive food consumption behaviors: a systematic review and meta-analysis. Int J Behav Nutr Phys Act. 2017;14(1):47.

9. Madruga SW, Araújo CLP, Bertoldi AD, Neutzling MB. Manutenção dos padrões alimentares da infância à adolescência. Rev Paul Pediatr. 2012;46:376-86.

10. Brito Silva AO, Oliveira AMC, Silva CMP, Oliveira DDJ, Silva Carrias DT, Araújo Rodrigues H, et al. Relação da alimentação com surgimento precoce da obesidade e diabetes mellitus tipo 2 em crianças e adolescentes. Reas. 2019(18):e90. https://doi.org/10.25248/reas.e90.2019

11. Steele EM, Juul F, Neri D, Rauber F, Monteiro CA. Dietary share of ultra-processed foods and metabolic syndrome in the US adult population. Prev Med. 2019;125:40-8.

12. Monteiro CA, Cannon G, Lawrence M, Costa Louzada ML, Machado PP. Ultra-processed foods, diet quality, and health using the NOVA classification system. Rome: Food and Agriculture Organization of the United Nations; 2019 [cited 2020 June 9]. Available from: http://www.fao.org/3/ca5644en/CA5644EN.pdf 
13. Rauber F, Campagnolo PDB, Hoffman DJ, Vitolo MR. Consumption of ultra-processed food products and its effects on children's lipid profiles: a longitudinal study. Nutri Metab Cardiovas. 2015;25(1):116-22.

14. Santos KC, Souza Marchesi JCL. A influência da mídia sobre a alimentação e o comportamento sedentário de crianças: uma revisão da literatura. J Health Sci Inst. 2018;36(4):281-4.

15. Dutra GF, Kaufmann CC, Pretto ADB, Albernaz EP. Television viewing habits and their influence on physical activity and childhood overweight. J Pediatr. 2015;91(4):346-51.

16. Vasconcellos MB, Anjos LA, Vasconcellos MTL. Estado nutricional e tempo de tela de escolares da Rede Pública de Ensino Fundamental de Niterói, Rio de Janeiro, Brasil. Cad Saúde Pública. 2013;29:713-22.

17. Pérez-Farinós N, Villar-Villaba C, Sobaler AML, Saavedra MAD, Aparicio A, Sanz SS, et al. The relationship between hours of sleep, screen time and frequency of food and drink consumption in Spain in the 2011 and 2013 ALADINO: a cross-sectional study. Bmc Public Health. 2017;17(1):33.

18. World Health Organization. Guidelines on physical activity, sedentary behaviour and sleep for children under 5 years of age. Geneva: Organization; 2019 [cited 2020 June 9]. Available from: https://apps.who.int/iris/ bitstream/handle/10665/311663/WHO-NMH-PND-19.2-eng.pdf

19. Oliveira JS, Barufaldi LA, Abreu GA, Leal VS, Brunken GS, Vasconcelos SML, et al. ERICA: use of screens and consumption of meals and snacks by Brazilian adolescents. Rev Saúde Públ. 2016;50:7s. https://doi. org/10.1590/S01518-8787.2016050006680

20. Hicks K, Pitts SJ, Lazorick S, Fang X, Rafferty A. Examining the association between screen time, beverage and snack consumption, and weight status among Eastern North Carolina Youth. N C Med. J. 2019;80(2):69-75. https://doi.org/10.18043/ncm.80.2.69

21. Ministério da Saúde (Brasil). Orientações para avaliação de marcadores de consumo alimentar na atenção básica. Brasília: Ministério; 2015 [citado 9 jun 2020]. Disponível em: http://bvsms.saude.gov.br/bvs/ publicacoes/marcadores_consumo_alimentar_atencao_basica.pdf

22. Lauritsen JM. EpiData Classic: data management and basic statistical analysis system. Odense: EpiData Association; 2008 [cited 2020 July 7]. Available from: http://www.epidata.dk

23. Stata Statistical Software: Release 15. College Station: StataCorp LLC; 2017.

24. Ministério da Saúde (Brasil). Guia alimentar para crianças brasileiras menores de 2 anos. Brasília: Ministério; 2019 [citado 9 jun 2020]. Disponível em: http://189.28.128.100/dab/docs/portaldab/publicacoes/ guia_da_crianca_2019.pdf

25. Silveira GLL, Neves LF, Pinho L. Fatores associados à alimentação entre crianças atendidas em creches públicas de Montes Claros. Rev Ass Bras Nutr. 2017;8(2):20-6.

26. Oliveira Brugger D. Fatores associados ao consumo alimentar de marcadores saudáveis e não saudáveis em crianças menores de cinco anos. Rev Med Minas Gerais. 2019;29:e-2034. https://doi.org/10.5935/22383182.20190052

27. Freitas Libanio IF, Silveira Correa R, Souza Monteiro A, Vallandro JP. Consumo de alimentos ultraprocessados em crianças atendidas pelo serviço de Atenção Básica na região Sul do Brasil. Int J Nutrol. 2019;12(1):35-40.

28. Sparrenberger K, Fridrich RR, Schiffner MD, Schuch I, Wagner MB. Ultra-processed food consumption in children from a Basic Health Unit. J Pediatr. 2015;91(6):535-42.

29. Toloni MHA, Longo-Silva G, Goulart RMM, Taddei JAAC. Introdução de alimentos industrializados e de alimentos de uso tradicional na dieta de crianças de creches públicas no município de São Paulo. Rev Nutr. 2011;24(1):61-70.

30. Jusienė $R$, Urbonas $V$, Laurinaitylê I, Rakickiené $L$, Breidokiené $M$, Kuzminskaitê, et al. Screen use during meals among young children: exploration of associated variables. Medicina. 2019;55(10):688. https://doi. org/10.3390/medicina55100688

31. Pearson N, Biddle SJH, Griffiths P, Johnston JP, Haycraft E. Clustering and correlates of screen-time and eating behaviours among young children. Bmc Public Health. 2018;18(1):753.

32. Sousa TM, Santos LC, Costa HTP, Carvalho RB, Pereira SCL. Factors associated with the consumption of food markers of unhealthy diet among school children in situations of high health vulnerability. J Trop Pediatr. 2019;65(6):576-82.

33. Melo KM, Cruz ACP, Brito MFSF, Pinho L. Influência do comportamento dos pais durante a refeição e no excesso de peso na infância. Esc Anna Nery. 2017;21(4):e20170102. https://doi.org/10.1590/2177-9465EAN-2017-0102 
34. Dantas RR, Silva GAP. O papel do ambiente obesogênico e dos estilos de vida parentais no comportamento alimentar infantil. Rev Paul Pediatr. 2019;37(3):363-71.

35. Fundo Nacional de Desenvolvimento da Educação (Brasil). FNDE atualiza normas do Programa Nacional de Alimentação Escolar. Brasília: Fundo; 2020 [citado 9 jun 2020]. Disponível em: http://www.fnde.gov.br/ index.php/acesso-a-informacao/institucional/area-de-imprensa/noticias/item/13514-fnde-atualiza-normasdo-programa-nacional-de-alimentação-escolar.

36. Longo-Silva G, Aguiar Toloni MH, Menezes RCE, Asakura L, Oliveira MAA, Taddei JAAC. Introdução de refrigerantes e sucos industrializados na dieta de lactentes que frequentam creches públicas. Rev Paul Pediatr. 2015;33(1):34-41.

37. Jaime PC, Prado RR, Malta DC. Influência familiar no consumo de bebidas açucaradas em crianças menores de dois anos. Rev Saúde Pública. 2017;51:13s. https://doi.org/10.1590/s1518-8787.2017051000038

38. Dalton MA, Longacre MR, Drake KM, Cleveland LP, Harris JL, Hendricks K, et al. Child-targeted fast-food television advertising exposure is linked with fast-food intake among pre-school children. Public Health Nutr. 2017;20(9):1548-56. 